\title{
PEMBELAJARAN JARAK JAUH DI MASA PANDEMI COVID-19: PERAN LITERASI DIGITAL DAN TASK VALUE TERHADAP SELF-REGULATED LEARNING MAHASISWA
}

\author{
Husnul Muasyaroh \& Lucia R. M. Royanto \\ Fakultas Psikologi, Universitas Indonesia, Kampus Baru UI Depok, Jawa Barat 16424, Indonesia \\ Korespondensi: husnul.muasyaroh@ui.ac.id
}

\section{DISTANCE LEARNING DURING COVID-19 PANDEMIC: ROLE OF DIGITAL LITERACY AND TASK VALUE TOWARDS SELF-REGULATED LEARNING IN COLLEGE STUDENTS}

\begin{abstract}
Distance learning has been primarily utilized by college students since COVID-19 pandemic Distance learning mode requires students to allocate and regulate their learning experience more independently. This study aimed to examine the role of digital literacy and task value on self-regulated learning of college students who participated in distance learning during COVID-19 pandemic. Participants were 420 college students across faculties from 10 public universities in Indonesia who agreed to fill the online survey consisting three validated measures. Regression analysis indicated that digital literacy and task value positively contribute to the participants' capacity of self-regulated learning. Further analysis suggested that, compared to digital literacy, task value is a stronger predictor of students' self-regulated. The finding could provide valuable insight to assist in developing policies or interventions to improve college students' self-regulated learning in distance learning.
\end{abstract}

Manuscript type: Original Research

Article history:

Received 26 August 2020

Received in revised form 1 October 2020

Accepted 26 November 2020

Available online 14 March 2021

\section{Keywords:}

college student

COVID-19

digital literacy

distance learning

self-regulated learning

task value

\begin{abstract}
Abstrak
Pembelajaran jarak jauh (PJJ) menjadi metode pembelajaran yang semakin banyak digunakan sebagai alternatif selama masa pandemi COVID-19 pada mahasiswa. Hal ini menyebabkan mahasiswa harus lebih mampu meregulasi proses belajarnya secara mandiri. Penelitian ini bertujuan untuk menguji pengaruh literasi digital dan task value terhadap self-regulated learning (SRL) pada mahasiswa jenjang sarjana yang mengikuti PJJ di masa pandemi COVID-19. Partisipan merupakan 420 mahasiswa dari berbagai fakultas di 10 perguruan tingg negeri Indonesia yang bersedia mengisi survei daring, yang terdiri dari tiga alat ukur yang telah divalidasi. Hasil analisis regresi menunjukkan bahwa terdapat pengaruh yang positif dan signifikan dari literasi digital dan task value secara bersama-sama terhadap kemampuan SRL. Task value juga diketahui memiliki kontribusi relatif yang lebih besar dibandingkan dengan literasi digital dalam memprediksi SRL mahasiswa. Temuan ini dapat menjadi dasar dalam menentukan kebijakan atau intervensi untuk meningkatkan kemampuan SRL pada mahasiswa yang mengikuti PJJ.
\end{abstract}

Kata Kunci: COVID-19, literasi digital, mahasiswa, pembelajaran jarak jauh (PJJ), self-regulated learning, task value

\section{Dampak dan Implikasi dalam Konteks Ulayat}

Pandemi COVID-19 memaksa terjadinya transformasi proses pembelajaran di perguruan tinggi Indonesia, yaitu dari tatap muka menjadi daring. Kondisi ini menuntut keaktifan mahasiswa untuk mengembangkan strategi belajarnya secara mandiri. Penelitian ini membuktikan bahwa keterampilan penggunaan perangkat digital yang baik dan penilaian positif terhadap perkuliahan dapat membantu mahasiswa untuk mandiri dalam meregulasi belajarnya selama PJJ. Penelitian ini dapat menjadi acuan dalam mendesain perkuliahan yang dapat membentuk penilaian positif mahasiswa terhadap perkuliahan, serta mengembangkan kompetensi penggunaan perangkat digital bagi pihak terkait, seperti mahasiswa, dosen, fakultas, hingga universitas, sehingga terjadi peningkatan kualitas pelaksanaan PJJ di masa pandemi COVID-19. 


\section{PENDAHULUAN}

Pada awal tahun 2020, World Health Organization menetapkan COVID-19 sebagai pandemi, yaitu penyakit yang menyebar secara global (WHO, 2020). Kasus COVID-19 mulai menginfeksi masyarakat Indonesia sejak awal Maret 2020 melalui terkonfirmasinya kasus positif dari dua Warga Negara Indonesia (WNI) yang berdomisili di Depok (Nuraini, 2020). Kemudian, pemerintah melakukan pencegahan untuk menghindari peningkatan kasus di Indonesia, termasuk di bidang penyelenggaraan pendidikan tinggi. Salah satunya adalah dengan mengeluarkan Surat Edaran Dirjen Dikti Kementerian Pendidikan dan Kebudayaan No. 1 Tahun 2020 yang mengharuskan perguruan tinggi menghentikan sementara model pembelajaran tatap muka dan menggantinya dengan model belajar dari rumah atau pembelajaran jarak jauh (PJJ) bagi mahasiswa dalam rangka pencegahan penyebaran COVID-19 (Kementerian Riset, Teknologi dan Pendidikan Tinggi [Kemenristekdikti], 2020).

Konsekuensinya, selama masa pandemi COVID-19, diketahui terjadi peningkatan penerapan PJJ, yang juga disebut sebagai distance learning, pada jenjang perguruan tinggi. Tercatat sebanyak 67 perguruan tinggi, baik negeri maupun swasta, yang telah menerapkan kuliah daring atau PJJ sejak awal tahun 2020 (Larasati, 2020). Sebenarnya beberapa perguruan tinggi seperti Universitas Indonesia (UI), Universitas Gajah Mada (UGM), Institut Pertanian Bogor (IPB), dan universitas lainnya telah berupaya menerapkan PJJ sebelum adanya pandemi (Putra, 2018), tetapi upaya ini terlihat lebih fokus di masa pandemi. Menurut Association to Advance Collegiate Schools of Business (AACSB, 2007), PJJ pada tingkat pendidikan tinggi adalah sistem pembelajaran yang mana perilaku pengajar terpisah dengan pelajar, tetapi tetap terhubung melalui beberapa bantuan media, seperti pesan telepon, audio, video, internet, dan sebagainya. PJJ merupakan model pembelajaran yang melibatkan berbagai media pengantar informasi, teknologi pembelajaran, dan instruksi yang dilakukan secara daring (Sadeghi, 2018). Hal ini menunjukkan bahwa model PJJ tidak dapat dilepaskan dari perkembangan teknologi sebagai media pembelajarannya. Model pembelajaran ini dianggap dapat menunjang model pengajaran di perguruan tinggi yang tidak lagi berpusat pada guru (teacher-centered), tetapi pada pelajar (student-centered) (Gosling, 2009).

Pergantian model pembelajaran dari tatap muka menjadi sepenuhnya PJJ membuat mahasiswa perlu beradaptasi dalam proses belajarnya. Beberapa penelitian menemukan beragam kesulitan yang mungkin muncul saat mengatur pembelajaran dalam lingkungan digital, misalnya tantangan bekerja kelompok secara virtual, berkomunikasi melalui teknologi, atau mengumpulkan informasi dari 
berbagai sumber digital (Blau dkk., 2020). Hal ini dikarenakan lingkungan digital adalah lingkungan hipermedia yang pelajarnya dapat menemui kesulitan dalam mengkombinasikan berbagai informasi yang berbeda, menentukan proses pembelajaran yang tepat, dan memilih sumber-sumber bantuan yang tepat (Azevedo dkk, 2008). Dalam konteks ini, mahasiswa bertanggung jawab untuk lebih aktif mengawasi dan mengatur proses belajarnya (Wang, 2011).

Dalam konteks PJJ, dibutuhkan kemampuan untuk mengatur proses pembelajaran secara aktif dan mandiri (Jansen dkk., 2016). Kemampuan ini dikenal dengan self-regulated learning (selanjutnya akan ditulis sebagai kemampuan SRL). Menurut Pintrich (2000), kemampuan SRL mencakup kemampuan individu untuk secara aktif menetapkan tujuan, mengawasi, mengatur, dan mengontrol strategi berpikir, motivasi, serta perilaku sesuai dengan tujuan dan konteks belajar selama proses pembelajaran. Kemampuan SRL akan membantu individu untuk mengelola informasi dan mengikuti proses belajar dalam lingkungan digital (Greene dkk., 2014). Beberapa hasil penelitian internasional menunjukkan bahwa mahasiswa atau pelajar yang terlibat dalam PJJ lebih banyak menggunakan strategi SRL dibandingkan dengan pelajar yang terlibat dalam metode tatap muka maupun metode yang memadukan pembelajaran daring dan tatap muka (blended learning) (Broadbent, 2017; Jansen dkk., 2016). Jelas bahwa kemampuan individu untuk meregulasi ekspektasi akademik merupakan prasyarat dalam kesiapan PJJ (Rivera, 2018). Oleh karena itu, kemampuan SRL sangat dibutuhkan dalam proses PJJ, sehingga penting untuk meneliti lebih lanjut terkait faktor-faktor yang berperan dalam kemampuan SRL.

Dalam PJJ, proses fundamental dari kemampuan SRL bergantung pada mekanisme desain materi yang dikembangkan, tutor yang memandu, dan pengalaman pembelajaran digital yang mendukung dan menfasilitasi SRL (Johnson \& Davies, 2014). Hal ini menjadi tantangan tersendiri karena materi atau informasi dari dosen tidak dapat tersampaikan secara langsung, melainkan harus disampaikan melalui seperangkat teknologi (Croft dkk., 2010). Perangkat teknologi mengambil alih sebagian besar peran pengajar, sehingga keterampilan dalam menggunakan berbagai perangkat teknologi diperlukan supaya mahasiswa dapat mengikuti pembelajaran dengan baik. Peechapol dkk. (2018) menjelaskan bahwa pengalaman dan pengetahuan terkait PJJ menjadi faktor yang memengaruhi keyakinan individu untuk belajar dalam lingkungan digital. Pengalaman dan pengetahuan tersebut berkaitan dengan penggunaan komputer atau teknologi informasi dan komunikasi lainnya. Hal ini erat kaitannya dengan literasi digital (Peechapol dkk., 2018).

Menurut Mohammadyari dan Singh (2015), literasi digital merupakan kemampuan individu untuk menggunakan perangkat dan peralatan digital untuk mencari, mengevaluasi, mengunakan, dan 
membuat informasi. Tang dan Chaw (2016) menyatakan bahwa literasi digital merupakan keterampilan prasyarat yang harus dimiliki individu untuk dapat belajar secara efektif dalam PJJ. Blayone (2018) juga menjelaskan bahwa kompetensi digital merupakan faktor penentu dalam kesiapan individu untuk belajar dalam PJJ. Terdapat pula beberapa penelitian yang menunjukkan adanya hubungan antara literasi digital dan kemampuan SRL dalam lingkungan digital (Lee dkk., 2015; Yang \& Kim, 2014). Hal ini menunjukkan bahwa interaksi dengan teknologi akan berdampak pada kemampuan SRL mahasiswa (Muthupoltotage \& Gardner, 2018).

Di sisi lain, Goetz dkk. (2013) menyebutkan bahwa emosi, motivasi, ketersediaan fasilitas, dan metakognisi terkait regulasi diri dalam belajar merupakan prediktor dari kemampuan SRL. Meskipun demikian, tiga dari enam model teoretis SRL, yaitu model dari Zimmerman (2000), Boekaerts (2007), dan Pintrich (2000) memberikan penekanan pada faktor motivasi dalam pembentukan SRL (Panadero, 2017). Hal ini dikarenakan beberapa penelitian terkait intervensi SRL menunjukkan hasil positif dalam konteks kelas, tetapi gagal digunakan dalam lingkungan belajar yang kurang terstruktur (Zimmerman \& Schunk, 2007). Dalam proses belajar saat PJJ, dialog (interaksi pengajar dan pelajar) dan struktur (desain pembelajaran) tidak dapat berjalan beriringan dan cenderung berkorelasi negatif (Demir Kaymak \& Horzum, 2013; Moore \& Kearsley, 2011). Artinya, ketika struktur ditingkatkan, maka dialog akan cenderung menurun dan begitu pula sebaliknya. Kesulitan dalam menyamakan proporsi dialog dan struktur membuat lingkungan belajar saat PJJ menjadi kurang terstruktur jika dibandingkan dengan kelas tatap muka. Dengan demikian, kemampuan SRL membutuhkan komponen motivasi, pengarahan diri, dan disiplin diri sebagai bagian dari pembelajaran kognitif dalam kelas-kelas virtual (Broadbent \& Poon, 2015; Croft dkk., 2010).

Pentingnya faktor motivasi memunculkan berbagai penelitian terkait hubungan antara sumber motivasi dengan kemampuan SRL dalam PJJ. Penelitian Swafford (2018) menunjukkan bahwa faktor motivasi, seperti intrinsic goal orientation, extrinsic goal orientation, task value, control of learning beliefs, efikasi diri, dan kecemasan menghadapi tes (test anxiety) berkorelasi positif dan signifikan terhadap kemampuan SRL. Meskipun demikian, hasil penelitian terbaru menunjukkan bahwa task value memiliki korelasi yang lebih tinggi terhadap kemampuan SRL dibandingkan variabel motivasi lain, seperti efikasi diri dalam PJJ (Lee dkk., 2020). Task value didefinisikan sebagai sebuah penilaian individu tentang seberapa menarik, penting, dan bergunanya sebuah tugas yang dapat mendorong individu untuk melakukan tugas tersebut (Pintrich dkk., 1991).

Berdasarkan uraian di atas, diasumsikan bahwa kemampuan literasi digital yang baik dengan disertai sumber motivasi terkait penilaian terhadap perkuliahan yang baik (task value) akan 
mengarahkan pada kemampuan SRL yang baik juga. Meskipun demikian, penelitian terdahulu lebih banyak melihat hubungan literasi digital dengan kemampuan SRL pada pembelajaran yang bersifat informal, seperti kursus daring atau pelatihan (Jannah, 2019; Muthupoltotage \& Gardner, 2018). Padahal, selama masa pandemi COVID-19 seluruh pembelajaran formal di perguruan tinggi Indonesia telah dilaksanakan dalam model PJJ (Kemenristekdikti, 2020). Hal ini tentu menciptakan pengalaman baru bagi dosen dan mahasiswa yang menjalankan PJJ dalam lingkup yang lebih besar dan masif, meskipun sebelumnya beberapa universitas diketahui telah menerapkan PJJ dalam skala kecil (Putra, 2018). Selama PJJ di masa pandemi COVID-19, diketahui juga bahwa mahasiswa menunjukkan kepuasan yang rendah dan masih kesulitan dalam proses belajarnya (Napitupulu, 2020). Oleh karena itu, kondisi ini mendukung untuk melakukan penelitian pada keadaan alamiah tanpa adanya pengkondisian untuk dapat menggambarkkan kondisi terkini terkait ketiga variabel penelitian ini selama PJJ di masa pandemi COVID-19 pada mahasiswa.

Berdasarkan penjelasan di atas, penelitian ini bertujuan untuk melihat peran literasi digital yang disertai dengan adanya sumber motivasi berupa task value terhadap kemampuan SRL pada mahasiswa yang mengikuti PJJ sebagai bagian dari pembelajaran formal dalam pendidikan tinggi. Hipotesis dalam penelitian ini adalah literasi digital dan task value secara bersama-sama berkontribusi terhadap kemampuan SLR mahasiswa. Hasil penelitian ini dapat digunakan sebagai acuan untuk membuat strategi yang lebih tepat dan spesifik untuk meningkatan kemampuan regulasi diri dalam belajar dengan melibatkan faktor motivasi dan kemampuan literasi digital pada mahasiswa yang mengikuti PJJ.

\section{METODE}

\section{Partisipan}

Partisipan merupakan mahasiswa jenjang S1 yang sedang mengikuti mengikuti PJJ dari 10 Perguruan Tinggi Negeri (PTN) peringkat teratas pada klaster 1 (Kemenristekdikti, 2019). Hal ini dilakukan untuk mengontrol pengaruh dari faktor eksternal dari pihak PTN seperti infrastruktur, sistem, dan desain PJJ yang dapat mempengaruhi variabel penelitian (Devolder dkk., 2012; Tuamsuk \& Subramaniam, 2017). PTN di Klaster 1 diasumsikan memiliki kualitas, akses, dan sistem pembelajaran jarak jauh yang setara atau tidak jauh berbeda, sehingga dapat meminimalisasi adanya pengaruh dari faktor tersebut. Pemilihan partisipan dilakukan dengan teknik aksidental dengan metode survei daring (Fricker, 2017). Jumlah partisipan yang diperoleh adalah 480 mahasiswa, tetapi 
setelah melalui pemeriksaan data tahap awal dengan cara menghapus outlier, data ganda (teridentifikasi melalui kesamaan waktu pengisian dan data demografis), dan data yang tidak sesuai kriteria, maka didapatkan 420 sampel $(M=20.04 ; S D=1.15)$ yang dianalisis.

\section{Desain}

Penelitian ini merupakan penelitian kuantitatif non-eksperimental, cross-sectional dengan menggunakan kuesioner sebagai alat untuk mengukur dua variabel independen (literasi digital dan task value) dan satu variabel dependen (SRL). Desain penelitian ini bertujuan untuk menangkap fenomena dari populasi secara alamiah (tanpa intervensi), sehingga didapatkan gambaran yang lebih nyata.

\section{Prosedur}

Proposal, protokol pelaksanaan, dan alat ukur penelitian ini telah disetujui oleh Komite Etika Penelitian Fakultas Psikologi Universitas Indonesia. Penelitian diawali dengan kajian literatur dan adaptasi alat ukur literasi digital dan task value. Adaptasi dilakukan dengan cara menerjemahan butir ke dalam Bahasa Indonesia dan menyesuaikan butir dengan konteks penelitian. Kemudian, teknik validitas isi adalah analisis rasional dari expert judgement digunakan untuk menguji validitas alat ukur. Selanjutnya, uji coba alat ukur dilakukan kepada 100 partisipan untuk mengetahui reliabilitas alat ukur. Setelah dinyatakan valid dan reliabel, alat ukur tersebut digunakan dalam pengambilan data akhir. Alat ukur dilengkapi dengan lembar persetujuan (informed consent) yang mana keikutsertaan partisipan penelitian bersifat anonim dan sukarela. Alat ukur disebarkan secara daring dengan menggunakan poster digital. Poster tersebut dibagikan di media sosial yang banyak diakses oleh mahasiswa, seperti Instagram, Twitter, dan Facebook, serta melalui group Line dan Whatsapp yang beranggotakan mahasiswa sesuai kriteria penelitian. Poster juga dibagikan secara personal dan dibantu oleh tenaga pendidik di universitas yang menjadi lingkup studi ini untuk menjangkau partisipan yang sesuai kriteria. Setiap pengisian alat ukur, partisipan dianggap berdonasi sebesar Rp2.000,00 untuk penanganan wabah COVID-19 di Indonesia yang disalurkan melalui laman kitabisa.com. Kemudian, filter data dilakukan di akhir pengumpulan data dengan cara menghapus data ganda dan data yang tidak sesuai kriteria penelitian. 


\section{Instrumen}

Penelitian ini menggunakan instrumen berupa kuesioner untuk mengumpulkan data terkait variabel literasi digital, task value, dan SRL. Terdapat tiga alat ukur yang digunakan, yaitu: 1) Skala Self-Regulated Online Learning (SROL) untuk mengukur variabel SRL; 2) Self-Perceived Evaluations of Digital Literacy Competencies (SPEDLC) untuk mengukur literasi digital; dan 3) The Subjective Task Value Instrument (STVI) untuk mengukur task value.

Skala Self-Regulated Online Learning (SROL) disusun oleh Arbiyah dan Triatmoko (2016) untuk mengukur kemampuan SRL dalam konteks PJJ. Alat ukur ini terdiri dari enam dimensi, yaitu goal setting, environmental structuring, task strategies, time management, help-seeking, dan selfevaluation (Arbiyah \& Triatmoko, 2016). Alat ukur ini menggunakan skala Likert dengan rentang angka 1 sampai 6 ( 1 = Sangat Tidak Sesuai; 6 = Sangat Sesuai). Setelah dilakukan uji coba alat ukur, didapatkan 18 butir dengan koefisien reliabilitas yang baik $(\alpha=.830)$.

Self-Perceived Evaluations of Digital Literacy Competencies (SPEDLC) dikembangkan oleh Porat dkk. (2018) dan disusun berdasarkan komponen literasi digital yang dikembangkan oleh Eshet (2012). Terdapat enam dimensi dalam alat ukur ini, yaitu photo-visual literacy, reproduction literacy, branching literacy, information literacy, socio-emotional literacy, dan real-time thinking literacy (Eshet, 2012). Alat ukur ini menggunakan skala Likert dengan rentang angka 1 sampai 6 (1 = Sangat Sulit; 6 = Sangat Mudah). Setelah dilakukan adaptasi dalam Bahasa Indonesia dan uji coba alat ukur, didapatkan 17 butir dengan koefisien reliabilitas yang baik $(\alpha=.841)$.

The Subjective Task Value Instrument (STVI) dikembangkan oleh Baig (2017). Alat ukur ini terdiri dari empat dimensi, yaitu attainment, intrinsic or interest, utility, dan cost. Namun, hanya tiga dimensi yang akan digunakan dalam penelitian ini. Hal ini dikarenakan subskala cost tidak termasuk dalam komponen dari task value karena dinilai lebih berperan sebagai faktor yang memengaruhi daripada sebagai komponen dari task value (Wigfield dkk., 2017). Partisipan menjawab melalui skala Likert dengan rentang angka 1 sampai 6 (1= Sangat Tidak Setuju; 6 = Sangat Setuju). Setelah dilakukan adaptasi dalam Bahasa Indonesia dan uji coba alat ukur, didapatkan 13 butir dengan koefisien reliabilitas yang baik $(\alpha=.803)$.

\section{Teknik Analisis}

Analisis data menggunakan uji regresi berganda. Seluruh proses analisis mulai dari uji asumsi hingga uji regresi berganda dilakukan dengan menggunakan program statistik, yaitu SPSS versi 22.0 for Windows. 


\section{ANALISIS DAN HASIL}

\section{Data Demografis Partisipan}

Berdasarkan data yang diperoleh, didapatkan gambaran demografis partisipan seperti yang tertera pada Tabel 1. Dari tabel tersebut diketahui bahwa sebagian besar partisipan penelitian merupakan mahasiswa perempuan (75.5\%) yang memiliki usia berkisar 20-22 tahun (63.1\%). Kemudian, sebagian besar partisipan sedang berada pada semester 3-6 (62.1\%). Meskipun persebaran universitas asal belum merata, tetapi terdapat perwakilan dari masing-masing universitas sampel penelitian. Partisipan paling banyak berasal dari Universitas Indonesia (18.8\%) dan daerah tempat tinggal partisipan terbanyak adalah di Pulau Jawa (85.9\%).

Tabel 1.

Gambaran Demografis Partisipan

\begin{tabular}{llcc}
\hline & Karakteristik Partisipan & $\mathbf{N}$ & $\mathbf{\%}$ \\
\hline & Laki-laki & 103 & 24.5 \\
& Perempuan & 317 & 75.5 \\
& & & \\
Usia & $17-19$ & 147 & 35.0 \\
& $20-22$ & 265 & 63.1 \\
& $23-25$ & 8 & 1.9 \\
Semester yang Sedang Ditempuh & $1-2$ & & \\
& $3-4$ & 111 & 26.4 \\
& $5-6$ & 124 & 29.5 \\
& $7-8$ & 137 & 32.6 \\
& $9-10$ & 46 & 11.0 \\
Perguruan Tinggi Saat ini & & 2 & .5 \\
& Institut Pertanian Bogor & & \\
& Institut Teknologi Bandung & 33 & 7.9 \\
& Institut Teknologi Sepuluh Nopember & 43 & 10.2 \\
& Universitas Airlangga & 26 & 6.2 \\
& Universitas Brawijaya & 49 & 11.7 \\
& Universitas Diponegoro & 31 & 7.4 \\
& Universitas Gadjah Mada & 38 & 9.0 \\
& Universitas Hasanuddin & 44 & 10.5 \\
& Universitas Indonesia & 24 & 5.7 \\
& Universitas Padjadjaran & 79 & 18.8 \\
& & 53 & 12.6 \\
& Sumatra & 22 & 5.2 \\
& Jawa & 361 & 85.9 \\
& Bali dan Nusa Tenggara & 4 & .9 \\
& Kalimantan & 5 & 1.1 \\
& Sulawesi & 25 & 5.9 \\
& Maluku dan Papua & .7 \\
\hline
\end{tabular}




\section{Korelasi Antar Variabel Penelitian}

Penelitian ini melakukan uji kolerasi Pearson menggunakan melihat hubungan masingmasing variabel independen terhadap variabel dependen (lihat Tabel 2). Literasi digital memiliki korelasi yang positif dan signifikan dengan kemampuan SRL $(r=.418 ; p=.000)$. Hal ini menunjukkan bahwa semakin tinggi literasi digital mahasiswa, maka semakin tinggi pula kemampuannya untuk meregulasi diri dalam belajar pada konteks PJJ. Selain itu, task value juga memiliki korelasi yang positif dan signifikan dengan kemampuan SRL $(r=.529 ; p=.000)$. Hal ini menunjukkan bahwa semakin tinggi penilaian mahasiswa terhadap perkuliahan, maka semakin tinggi pula kemampuannya untuk meregulasi diri dalam belajar pada konteks PJJ.

Tabel 2.

Matriks Korelasi antar Variabel

\begin{tabular}{|c|c|c|c|}
\hline Alat Ukur & (1) & (2) & (3) \\
\hline (1) SROL (Range $=46-103 ; M=75.29 ; S D=11.65$ ) & 1 & & \\
\hline (2) $\operatorname{SPEDLC}$ (Range $=59-102 ; M=81.20 ; S D=9.36$ ) & $.418^{* *}$ & 1 & \\
\hline (3) STVI (Range $=42-78 ; M=61.54 ; S D=7.03$ ) & $.529^{* *}$ & $.350^{* *}$ & 1 \\
\hline
\end{tabular}

Catatan: ${ }^{* *}=$ Signifikan pada level $.001 ;$ SROL $=$ Self-Regulated Online Learning; SPEDLC $=$ Self-Perceived Evaluations of Digital Literacy Competencies; STVI = The Subjective Task Value Instrument

\section{Uji Asumsi Klasik}

Hasil uji asumsi yang meliputi uji normalitas $(p=.174)$, uji linearitas $(p=.000)$, uji multikolonieritas (tolerance $=.877 ;$ VIF $=1.140$ ), dan uji heterodeksitas (grafik tidak berpola khusus) menunjukkan bahwa data penelitian ini memenuhi uji asumsi klasik sebagai syarat uji regresi.

\section{Pengaruh Literasi Digital dan Task Value terhadap Self-Regulated Learning}

Uji hipotesis dilakukan dengan metode regresi linear berganda menunjukkan adanya pengaruh yang signifikan dari dua variabel independen terhadap variabel dependen (lihat Tabel 3). Literasi digital dan task value secara bersama-sama memiliki sumbangan pengaruh sebesar $33.9 \%(F(2,417)$ $\left.=108.325 ; p=.000 ; R^{2}=0.339\right)$ terhadap kemampuan SRL. Menurut Gravetter dan Wallnau (2017), effect size dapat dikatakan memiliki efek besar jika nilai $R^{2}$ lebih besar dari .25. Dalam studi ini, dapat disimpulkan bahwa kontribusi literasi digital dan task value secara bersama-sama memiliki efek yang besar terhadap kemampuan SRL. 
Pada penelitian ini, diketahui bahwa literasi digital juga signifikan memprediksi kemampuan SRL $(\beta=.265 ; p=.000)$ sebagaimana task value secara signifikan memprediksi kemampuan SRL $(\beta$ $=.436 ; p=.000)$. Hasil ini menunjukkan bahwa masing-masing variabel independen secara signifikan memengaruhi variabel dependen, tetapi task value memiliki nilai pengaruh yang lebih tinggi dibandingkan kemampuan literasi digital (lihat Tabel 3).

Tabel 3.

Ringkasan Hasil Analisis Regresi

\begin{tabular}{ccccccc}
\hline Variabel Independen & $\boldsymbol{B}$ & $\boldsymbol{S E} \boldsymbol{B}$ & $\boldsymbol{\beta}$ & $\boldsymbol{R}$ & $\boldsymbol{R}^{\mathbf{2}}$ & ${\text { Adjusted } \boldsymbol{R}^{2}}^{2}$ \\
\hline Konstanta & 3.951 & 4.932 & & & & \\
Literasi digital & .330 & .053 & $.265^{* *}$ & $.585^{* *}$ & .342 & .339 \\
Task value & .723 & .070 & $.436^{* *}$ & & & \\
\hline
\end{tabular}

Catatan: * = Signifikan pada level .05; ** signifikan pada level .001; Variabel Dependen $=$ Self-Regulated Learning (SRL)

\section{DISKUSI}

Penelitian ini bertujuan untuk melihat peran literasi digital yang disertai dengan adanya sumber motivasi berupa task value terhadap kemampuan SRL pada mahasiswa yang mengikuti PJJ sebagai bagian dari pembelajaran formal dalam pendidikan tinggi. Hasil analisis data menunjukkan bahwa terdapat pengaruh yang signifikan dan positif dari literasi digital dan task value secara bersama-sama terhadap kemampuan SRL pada mahasiswa yang mengikuti PJJ. Literasi digital dan task value secara bersama-sama memiliki konstribusi sebesar 33.9\% terhadap kemampuan SRL. Hal ini menunjukkan bahwa literasi digital dan task value berperan penting untuk memprediksi kemampuan SRL pada mahasiswa yang mengikuti PJJ, yang berarti kemampuan literasi digital yang baik disertai dengan penilaian terhadap perkuliahan yang baik akan dapat meningkatkan kemampuan SRL pada mahasiswa yang mengikuti PJJ.

Penelitian ini dapat membuktikan bahwa mahasiswa yang memiliki literasi digital yang baik dapat mendukung kemampuan SRL. Apabila dilihat dari respons partisipan, dapat dilihat bahwa ratarata mahasiswa memiliki literasi digital yang cukup baik, terutama dalam mencari, memahami, dan menggunakan referensi informasi dari internet, serta dapat berkomunikasi dengan baik di media sosial. Hal ini akan mendukung kemampuan SRL mahasiswa selama mengikuti PJJ di masa pandemi 
COVID-19. Menurut Tang dan Chaw (2016), literasi digital merupakan keterampilan prasyarat yang harus dimiliki individu untuk dapat belajar secara efektif dalam konteks PJJ. Hal ini dikarenakan selama PJJ, individu akan mendapatkan materi dan instruksi tidak secara langsung melalui pengajar, tetapi melalui perangkat teknologi (Johnson \& Davies, 2014). Literasi digital akan membantu mahasiswa dalam melakukan pengaturan terkait lingkungan belajar yang melibatkan teknologi, sehingga membantu mahasiswa tersebut untuk meregulasi proses belajarnya. Hasil penelitian ini juga sejalan dengan beberapa hasil penelitian yang menunjukkan adanya hubungan positif yang signifikan antara literasi digital dan kemampuan SRL dalam lingkungan digital (Lee dkk., 2015; Jannah, 2019; Muthupoltotage \& Gardner, 2018; Yang \& Kim; 2014).

Selain itu, pengalaman dan pengetahuan terkait PJJ menjadi faktor yang memengaruhi keyakinan individu untuk belajar dalam lingkungan digital (Peechapol dkk., 2018). Dengan kata lain, pengalaman dan pengetahuan terkait PJJ sebagai bagian dari literasi digital akan membuat individu lebih yakin dan merasa mampu untuk dapat belajar dalam konteks PJJ. Keyakinan atas kemampuannya tersebut akan menjadi salah satu sumber motivasi bagi individu untuk dapat meregulasi proses belajarnya secara mandiri selama PJJ (Lee dkk., 2020; Swafford, 2018). Dengan demikian, pengalaman dalam pembelajaran digital sebagai bagian dari kemampuan literasi digital dapat mendukung dan menfasilitasi kemampuan SRL mahasiswa pada konteks PJJ.

Selain literasi digital, keberadaan task value juga berpengaruh secara positif dan signifikan terhadap kemampuan SRL. Artinya, penilaian terhadap perkuliahan yang baik akan mendorong individu untuk dapat meregulasi proses belajarnya secara mandiri. Hasil ini didukung oleh beberapa penelitian yang menunjukkan adanya hubungan positif yang signifikan antara task value dan kemampuan SRL dalam konteks PJJ (Lee dkk., 2020; Swafford, 2018). Sebagai bagian dari faktor motivasi, penilaian individu terhadap perkuliahan (task value) memegang peranan penting dalam pembentukan kemampuan SRL (Panadero, 2017; Swafford, 2018). Hal ini dikarenakan penilaian terhadap tugas (task value) merupakan alasan pendorong individu untuk terlibat dalam sebuah tugas atau pembelajaran.

Menurut Velez (2008), keyakinan seseorang untuk menyelesaikan sebuah tugas, tidak selalu diikuti dengan penyelesaian tugas karena ia tidak memiliki alasan (pendorong) untuk menuntaskan tugas tersebut. Dengan kata lain, meskipun individu merasa mampu atas kemampuannya, tetapi jika ia melihat tugas atau perkuliahan sebagai sesuatu yang tidak penting, maka ia akan kurang terdorong untuk melakukan hal tersebut. Dalam konteks PJJ, individu dengan penilaian terhadap perkuliahan 
(task value) yang baik kemungkinan akan lebih terdorong untuk meregulasi proses belajarnya secara mandiri, sehingga dapat menyelesaikan tugas-tugasnya dengan baik.

Uraian di atas menunjukkan bagaimana keberadaan kemampuan literasi digital dan task value secara bersama-sama dapat mendukung kemampuan SRL mahasiswa pada konteks PJJ. Meskipun demikian, hasil penelitian ini menunjukkan bahwa task value memiliki nilai pengaruh yang lebih tinggi dibandingkan kemampuan literasi digital. Artinya, task value memiliki peran yang lebih besar dibandingkan kemampuan literasi digital dalam mendukung dan menfasilitasi kemampuan SRL mahasiswa pada konteks PJJ. Hal ini dikarenakan penggunaan teknologi sebagai media belajar membutuhkan disiplin dan motivasi diri yang tinggi, terutama jika menghadapi kesulitan dalam menggunakan perangkat tersebut (Croft dkk., 2010). Penilaian individu terhadap pentingnya proses perkuliahan dapat menjadi pendorong individu untuk bertahan dan menghadapi situasi sulit saat PJJ. Hal ini juga sejalan dengan tiga dari enam model teoretis SRL yang memberikan penekanan pada faktor motivasi, seperti task value dalam pembentukan SRL (Panadero, 2017).

Selain itu, hasil penelitian ini menunjukkan bahwa task value memegang peran yang lebih besar dalam mendukung kemampuan SRL mahasiswa pada lingkungan pembelajaran seperti PJJ. Hal ini karena task value merupakan bagian dari komponen motivasi yang dibutuhkan dalam membentuk kemampuan SRL dalam kelas-kelas virtual (Broadbent \& Poon, 2015). Menurut Croft dkk. (2010), tantangan dari PJJ adalah minimnya kontak dan interaksi langsung antara pelajar dengan pengajar maupun dengan sesama pelajar lainnya. Hal ini membuat proses belajar saat PJJ menjadi kurang terstruktur dan terkontrol jika dibandingkan dengan pembelajaran di kelas tatap muka. Beberapa penelitian terkait intervensi SRL juga menunjukkan adanya hasil yang positif dalam konteks kelas, tetapi gagal digunakan pada konteks yang kurang terstruktur (Zimmerman \& Schunk, 2007). Saat PJJ, individu akan lebih banyak melakukan pengaturan belajar secara mandiri sehingga membutuhkan peran task value yang baik sebagai bagian dari faktor motivasi agar dapat menghadapi tantangan belajar dalam lingkungan digital.

Hasil penelitian juga menunjukkan adanya sumbangan pengaruh variabel lain selain literasi digital dan task value terhadap kemampuan SRL pada mahasiswa yang mengikuti PJJ. Kedua variabel dalam penelitian ini merupakan bagian dari karakteristik pelajar (learner characteristics) sebagai faktor internal yang memengaruhi kemampuan SRL (Devolder dkk., 2012). Pengaruh variabel lain ditunjukkan dengan empat dari enam komponen dalam kemampuan SRL, yaitu environmental structuring, task strategies, manajemen waktu, dan help-seeking yang berkaitan dengan regulasi individu terhadap lingkungan eksternalnya (Barnard dkk., 2008). Misalnya, task strategies dan help- 
seeking berkaitan dengan karakteristik tugas (task characteristic) dan desain pembelajaran (scaffolding design) pada saat PJJ. Devolder dkk. (2012) menyatakan bahwa kedua faktor tersebut merupakan faktor yang juga dapat memengaruhi kemampuan SRL dalam konteks PJJ. Variabelvariabel dalam faktor tersebut dapat menjadi variabel lain yang kemungkinan memengaruhi kemampuan SRL dalam konteks PJJ, selain literasi digital dan task value yang telah diteliti dalam penelitian ini.

Meskipun demikian, terdapat sejumlah keterbatasan dalam penelitian ini. Pertama, teknik pengambilan sampel yang digunakan bukan merupakan teknik sampel acak, sehingga hasil penelitian ini tidak dapat digeneraliasi pada keseluruhan populasi yang dituju. Selain itu, proporsi keterwakilan partisipan dari segi jenis kelamin, universitas, dan daerah asal juga tidak setara. Kemudian, desain penelitian hanya menggunakan desain studi cross-sectional sehingga penjelasan hubungan sebabakibat dalam penelitian ini cukup terbatas. Pengukuran kemampuan literasi digital juga hanya dilakukan dengan metode self-report yang memungkinkan adanya perbedaan skor dengan pengukuran kemampuan literasi digital yang dilihat langsung melalui performa aktual (Porat, dkk., 2018). Penelitian ini juga tidak mempertimbangkan faktor internal, seperti pengalaman terlibat dalam PJJ atau faktor eksternal, seperti dukungan teman sebaya dan instruksi dosen. Padahal, variabel tersebut juga dapat berperan dalam mendukung kemampuan SLR pada saat PJJ.

\section{SIMPULAN DAN SARAN}

\section{Simpulan}

Berdasarkan uraian di atas, dapat disimpulkan bahwa literasi digital dan task value secara bersama-sama berpengaruh secara signifikan terhadap kemampuan SRL pada mahasiswa yang mengikuti PJJ. Selain itu, masing-masing variabel independen, yaitu literasi digital dan task value juga secara signifikan dapat memprediksi kemampuan SRL. Meskipun demikian, task value memiliki nilai korelasi yang lebih besar dalam memprediksi kemampuan SRL dibandingkan dengan literasi digital.

\section{Saran Teoretis}

Terdapat beberapa saran teoretis untuk penelitian selanjutnya supaya dapat mengatasi keterbatasan-keterbatasan yang ada pada penelitian ini. Pertama, penelitian selanjutnya diharapkan menggunakan teknik pengambilan sampel acak dalam pengambilan sampel untuk mengatasi 
keterbatasan dalam generalisasi populasi yang dituju. Jika teknik pengambilan sampel acak tidak memungkinkan, maka dapat dilakukan replikasi penelitian pada karakteristik sampel yang berbeda, seperti mahasiswa dari perguruan tinggi swasta atau kluster 2 dan 3 dari Kemenristekdikti (2019). Kedua, studi selanjutnya dapat menambahkan pengukuran performa aktual dari kemampuan literasi digital untuk memberikan gambaran yang lebih komprehensif terkait kemampuan literasi digital individu. Ketiga, melakukan penelitian dengan desain eksperimen untuk mengeksplor lebih lanjut hubungan sebab-akibat antar variabel. Keempat, studi selanjutnya dapat menguji pengaruh variabel lain terhadap kemampuan SRL, seperti pengalaman terlibat PJJ yang berkaitan dengan faktor karakteristik mahasiswa (learner characteristics) atau dukungan dosen yang berkaitan dengan faktor desain pembelajaran (scaffolding design) dan karakteristik tugas (task characteristics) (Devolder dkk., 2012).

\section{Saran Praktis}

Hasil penelitian ini dapat menjadi acuan untuk membuat strategi peningkatan kemampuan regulasi diri dalam belajar dengan melibatkan task value dan literasi digital. Bagi pengajar, kedua faktor tersebut dapat dipertimbangkan untuk menyesuaikan silabus dengan konteks mahasiswa selama PJJ. Misalnya, pengajar memanfaatkan perangkat atau platform digital yang relevan dan mudah digunakan atau memasukkan unsur task value (attainment, instrinsic, dan utility value) dalam menyampaikan materi perkuliahan. Sementara itu, mahasiswa dapat mempelajari berbagai platform yang menunjang proses belajar dan menilai perkuliahan secara positif untuk mendukung kemampuan SRL saat PJJ. Selain itu, mahasiswa juga perlu memahami pentingnya proses perkuliahan yang dijalani agar termotivasi untuk meregulasi proses belajar secara lebih efektif selama mengikuti PJJ. Kemudian, pihak fakultas dan universitas dapat memberikan pelatihan penggunaan media digital untuk proses pembelajaran yang efektif kepada mahasiswa dan dosen, serta meningkatkan kualitas sistem pembelajaran daring yang dimiliki agar lebih mudah diakses dan digunakan.

\section{REFERENSI}

Arbiyah, N., \& Triatmoko, F. (2016). Pengembangan Skala Regulasi Diri dalam pembelajaran daring (Self-Regulated Online Learning Scale) pada mahasiswa. Jurnal Ilmiah Psikologi MINDSET, 7(2), 20-32. http://journal.univpancasila.ac.id/index.php/mindset/article/view/ 311 
Association to Advance Collegiate Schools of Business International. (2007). Quality issues in distance learning. The Association to Advance Collegiate Schools of Business. https://numerons.files.wordpress.com/2012/04/16quality-issues-in-distance-learning.pdf

Azevedo, R., Moos, D. C., Greene, J. A., Winters, F. I., \& Cromley, J. G. (2008). Why is externallyfacilitated regulated learning more effective than self-regulated learning with hypermedia? Educational Technology Research and Development, 56(1), 45-72. https://doi.org/10.1007/s11423-007-9067-0

Baig, A. (2017). Relationship between the subjective task value of a course and level of transfer displayed by learners of cognitive behavioral theories (Publication No. 10634406) [Master's thesis, University of Arizona]. ProQuest Dissertations and Theses Global. https://search.proquest.com/docview/1988279560?accountid=17242

Barnard, L., Paton, V., \& Lan, W. (2008). Online self-regulatory learning behaviors as a mediator in the relationship between online course perceptions with achievement. The International Review of Research in Open and Distributed Learning, 9(2). 1-11. https://doi.org/10.19173/irrodl.v9i2.516

Blau, I., Shamir-Inbal, T., \& Avdiel, O. (2020). How does the pedagogical design of a technologyenhanced collaborative academic course promote digital literacies, self-regulation, and perceived learning of students? The Internet and Higher Education, 45(100722), 1-35. https://doi.org/10.1016/j.iheduc.2019.100722

Blayone, T. (2018). Reexamining digital-learning readiness in higher education: Positioning digital competencies as key factors and a profile application as a readiness tool. International Journal on E-Learning: Corporate, Government, Healthcare, and Higher Education, 17(4), 425-451. https://www.researchgate.net/publication/327815545

Boekaerts, M. (2007). Understanding students' affective processes in the classroom. Dalam P. Schutz \& R. Pekrun (Eds.), Emotion in education (hlm. 37-56). Academic Press.

Broadbent, J. (2017). Comparing online and blended learner's self-regulated learning strategies and academic performance. The Internet and Higher Education, 33, 24-32. http://doi.org/10.1016/j.iheduc.2017.01.004

Broadbent, J., \& Poon, W. L. (2015). Self-regulated learning strategies \& academic achievement in online higher education learning environments: A systematic review. The Internet and Higher Education, 27, 1-13. https://doi.org/10.1016/j.iheduc.2015.04.007 
Croft, N., Dalton, A., \& Grant, M. (2010) Overcoming isolation in distance learning: Building a learning community through time and space. Journal for Education in the Built Environment, 5(1), 27-64. https://doi.org/10.11120/jebe.2010.05010027

Demir Kaymak, Z., \& Horzum, M. B. (2013). Relationship between online learning readiness and structure and interaction of online learning students. Educational Sciences: Theory and Practice, 13(3), 1792-1797. https://doi.org/10.12738/estp.2013.3.1580

Devolder, A., van Braak, J., \& Tondeur, J. (2012). Supporting self-regulated learning in computerbased learning environments: Systematic review of effects of scaffolding in the domain of science education. Journal of Computer Assisted Learning, 28(6), 557-573. https://doi.org/10.1111/j.1365-2729.2011.00476.x

Eshet, Y. (2012). Thinking in the digital era: A revised model for digital literacy. Issues in Informing Science and Information Technology, 9(2), 267-276. https://www.researchgate.net/publication/312281798

Fricker, R. D. (2017). Sampling methods for online surveys. Dalam N. G. Fielding, R. M. Lee, \& G. Blank (Eds.), The SAGE handbook of online research methods (hlm. 184-202). Sage Publications.

Goetz, T., Nett, U. E., \& Hall, N. C. (2013). Self-regulated learning. Dalam N. C. Hall \& T. Goetz (Eds.), Emotion, motivation, and self-regulation: a handbook for teachers (hlm. 123-166). Emerald Group Publishing Limited.

Gosling, D. (2009). Supporting student learning. Dalam H. Fry, S. Ketteridge, \& S. Marshall (Eds.), A handbook for teaching and learning in higher education: Enhancing academic practice (hlm. 113-131). Routledge.

Gravetter, F. J., \& Wallnau, L. B. (2017). Statistics for the behavioral sciences (10th ed.). Cengage Learning.

Greene, J. A., Seung, B. Y., \& Copeland, D. Z. (2014). Measuring critical components of digital literacy and their relationships with learning. Computers \& Education, 76, 55-69. https://doi.org/10.1016/j.compedu.2014.03.008

Jannah, S. M. (2019). Analysis level of digital literacy of digital natives: How the impact on their self-regulated learning? Jurnal Bisnis dan Manajemen, 3(2), 173-185. http://dx.doi.org/10.25139/ekt.v3i2.1756 
Jansen, R. S., van Leeuwen, A., Janssen, J., Kester, L., \& Kalz, M. (2016). Validation of the selfregulated online learning questionnaire. Journal of Computing in Higher Education, 29(1), 6-27. https://doi.org/10.1007/s12528-016-9125-x

Johnson, G., \& Davies, S. (2014). Self-regulated learning in digital environments: Theory, research, praxis. British Journal of Research, 1(2), 1-14.

Kementerian Riset, Teknologi dan Pendidikan Tinggi. (2019, Agustus 16). Menristekdikti umumkan klasterisasi perguruan tinggi Indonesia 2019, fokuskan hasil dari perguruan tinggi. https://www.ristekbrin.go.id/kabar/menristekdikti-umumkan-klasterisasi-perguruan-tinggiindonesia-2019-fokuskan-hasil-dari-perguruan-tinggi/

Kementerian Riset, Teknologi dan Pendidikan Tinggi. (2020, Maret 16). Surat edaran pencegahan Corona Virus Disease (COVID-19) pada perguruan tinggi di lingkungan LLDIKTI Wilayah VII. http://lldikti7.ristekdikti.go.id/pengumumanDetail.php?id=23305

Larasati, C. (2020, Maret 15). Dampak korona, kuliah online diberlakukan di 67 Kampus. Medcom. https://www.medcom.id/pendidikan/news-pendidikan/JKRGRz3N-dampak-korona-kuliahonline-diberlakukan-di-67-kampus

Lee, D., Watson, S. L., \& Watson, W. R. (2020). The relationships between self-efficacy, task value, and self-regulated learning strategies in massive open online courses. The International Review of Research in Open and Distributed Learning, 21(1), 23-39. https://doi.org/10.19173/irrodl.v20i5.4389

Lee, J., Moon, J., \& Cho, B. (2015). The mediating role of self-regulation between digital literacy and learning outcomes in the digital textbook for middle school English. Educational Technology International, 16(1), 58-83.

Moore, M. G., \& Kearsley, G. (2011). Distance education: A systems view of online learning. Cengage Learning.

Muthupoltotage. U., P., \& Gardner, L. (2018). Analysing the relationships between digital literacy and self-regulated learning of undergraduates-A preliminary investigation. Dalam $\mathrm{N}$. Paspallis, M. Raspopoulos, C. Barry, M. Lang, H. Linger, \& C. Schneider (Eds.), Advances in information systems development (hlm. 1-16). Springer International Publishing.

Napitupulu, R. M. (2020). Dampak pandemi Covid-19 terhadap kepuasan pembelajaran jarak jauh. Jurnal Inovasi Teknologi Pendidikan, 7(1), 23-33. https://doi.org/10.21831/jitp.v7i1.32771 
Nuraini, R. (2020, Maret 2). Kasus COVID-19 pertama, masyarakat jangan panik. Indonesia. Indonesia.go.id. https://indonesia.go.id/narasi/indonesia-dalam-angka/ekonomi/kasusCOVID-19-pertama-masyarakat-jangan-panik

Panadero, E. (2017). A review of self-regulated learning: Six models and four direction for research. Frontiers in Psychology, 8, 1-28. https://doi.org/10.3389/fpsyg.2017.00422

Peechapol, C., Na-Songkhla, J., Sujiva, S., \& Luangsodsai, A. (2018). An exploration of factors influencing self-efficacy in online learning: A systematic review. International Journal of Emerging Technologies in Learning (iJET), 13(9), 64-86. https://doi.org/10.3991/ijet.v13i09.8351

Pintrich, P. R. (2000). The role of goal orientation in self-regulated learning. Dalam M. Boekaerts, P. Pintrich, \& M. Zeidner (Eds.), Handbook of self-regulation (hlm. 451-502). Academic Press.

Pintrich, P. R. R., Smith, D., Garcia, T., \& McKeachie, W. (1991). A manual for the use of the Motivated Strategies for Learning Questionnaire (MSLQ). https://files.eric.ed.gov/fulltext/ED338122.pdf

Porat, E., Blau, I., \& Barak, A. (2018). Measuring digital literacies: Junior high-school students' perceived competencies versus actual performance. Computers \& Education, 126, 23-36. https://doi.org/10.1016/j.compedu.2018.06.030

Putra, P. H. (2018, Juli 24). Akselerasi e-learning dan online education di tanah air. https://www.cs.ui.ac.id/index.php/akselerasi-e-learning-dan-online-education-di-tanahair/?lang=en pada tanggal 03 April 2020

Rivera, J. H. (2018). Online learner readiness: Strategies for success. Kappa Delta Pi Record, 54(2), 52-55. https://doi.org/10.1080/00228958.2018.1443679

Sadeghi, S. H. (2018). E-learning practice in higher education: A mixed-method comparative analysis. Springer.

Swafford, M. (2018). The relationship between motivation and online self-regulated learning. Journal of Human Sciences and Extension, 6(3), 92-106. https://www.jhseonline.com/article/view/791

Tang, C. M., \& Chaw, L. Y. (2016). Digital literacy: A prerequisite for effective learning in a blended learning environment? Electronic Journal of e-Learning, 14(1), 54-65.

Tuamsuk, K., \& Subramaniam, M. (2017). The current state and influential factors in the development of digital literacy in Thailand's higher education. Information and Learning Science, 118(5/6), 235-251. https://doi.org/10.1108/ILS-11-2016-0076 
Velez, J. (2008). Instructor communication behaviors and classroom climate: Exploring relationships with student self-efficacy and task value motivation [Doctoral dissertation, School of The Ohio State University]. OhioLINK. https://etd.ohiolink.edu/apexprod/rws_etd/send_file/send?accession=osu1211151901\&disp osition=inline

Wang, T. H. (2011). Developing Web-based assessment strategies for facilitating junior high school students to perform self-regulated learning in an e-Learning environment. Computers \& Education, 57(2), 1801-1812. https://doi.org/10.1016/j.compedu.2011.01.003

Wigfield, A., Rosenzweig, E., \& Eccles, J. (2017). Achievement values: Interactions, intervention, and future directions. Dalam A. J. Elliot, C. S. Dweck, \& D. S. Yeager (Eds.), Handbook of competence and motivation: Theory and application (hlm. 116-134). The Guilford Press.

World Health Organization. (2020, April 27). Archieved: WHO timeline Covid - 19. https://www.who.int/news-room/detail/27-04-2020-who-timeline---COVID-19

Yang, M., \& Kim, J. (2014). Correlation between digital literacy and self-regulated learning skills of learners in university e-Learning environment. Advanced Science and Technology Letters, 71, 80-83. http://dx.doi.org/10.14257/ast1.2014.71.19

Zimmerman, B. J., \& Schunk, D. H. (2007). Motivation: An essential dimension of self-regulated learning. Dalam D. H. Schunk \& B. J. Zimmerman (Eds.), Motivation and self-regulated learning: Theory, research, and applications (hlm. 1-30). Taylor \& Francis. https://books.google.co.id/books?id=MDQLfOg0jX0C

Zimmerman, B. J. (2000). Attaining self regulation: A social cognitive perspective. Dalam M. Boekaerts, P. Pintrich, \& M. Zeidner (Eds.), Handbook of self-regulation (hlm. 451-502). Academic Press. 